\title{
MIGRATION DECISIONS IN ARCTIC ALASKA: EMPIRICAL EVIDENCE OF THE STEPPING STONES HYPOTHESIS
}

\author{
by
}

\author{
Lance Howe * \\ University of Alaska Anchorage
}

and

Lee Huskey *

University of Alaska Anchorage

CES 10-41

December 2010

The research program of the Center for Economic Studies (CES) produces a wide range of economic analyses to improve the statistical programs of the U.S. Census Bureau. Many of these analyses take the form of CES research papers. The papers have not undergone the review accorded Census Bureau publications and no endorsement should be inferred. Any opinions and conclusions expressed herein are those of the author(s) and do not necessarily represent the views of the U.S. Census Bureau. All results have been reviewed to ensure that no confidential information is disclosed. Republication in whole or part must be cleared with the authors.

To obtain information about the series, see www.census.gov/ces or contact Cheryl Grim, Editor, Discussion Papers, U.S. Census Bureau, Center for Economic Studies 2K130B, 4600 Silver Hill Road, Washington, DC 20233, CES.Papers.List@census.gov. 


\begin{abstract}
This paper explores hypotheses of hierarchical migration using data from the Alaskan Arctic. We focus on migration of Iñupiat people, who are indigenous to the region, and explore the role of income, harvests of subsistence resources, and other place characteristics in migration decisions. To test related hypotheses we use confidential micro-data from the US Census Bureau's 2000 Decennial Census of Population and Income. Using predicted earnings and subsistence along with place invariant characteristics we generate migration probabilities using a mixed multinomial and conditional logit model. Our results support stepwise migration patterns, both up and down an urban and rural hierarchy. At the same time, we also identify differences between men and women, and we find mixed effects of place amenities and predicted earnings.
\end{abstract}

* Any opinions and conclusions expressed herein are those of the authors and do not necessarily represent the views of the U.S. Census Bureau. All results have been reviewed to ensure that no confidential information is disclosed. Support for this research the UCLA RDC from NSF (ITR-0427889) is also gratefully acknowledged. This material is based upon work supported by the National Science Foundation under Grant No. 0457662. 


\section{Introduction}

In this paper we use US Census microdata from arctic Alaska places to test for hierarchical migration patterns and to explore the effects of relative wages, subsistence harvests, and gender on migration decisions. In general we find strong evidence of hierarchical migration patterns, important gender differences in migration, and varied effects of relative wages and place amenities on migration.

Our research on hierarchical migration tests for phenomena first addressed in empirical literature over 100 years ago. In the late 19th century geographer Ernst Ravenstein published the "Laws of Migration" and his focus was primarily on the role of distance in the migration decision (Ravenstein, 1885; 1889). Ravenstein showed that for England, Scotland, and Ireland migration occurred in small geographic steps. Information on employment opportunities easily transfers between places in close proximity and individuals move to improve relative earnings. As Ravenstein (1889) noted, "under normal conditions the migratory movement will be a gradual one; it will proceed step by step, and will be transmitted from province to province until it makes itself felt in the most remote among them. ...If this really is so then the bulk of the migrants ought to travel short distances only, and that they really do this ... I believe I have amply proved."

Since Ravenstein, other research has re-characterized step-wise migration, moving from concepts of place to place hierarchical migration to regional hierarchical migration. That is, individual or family units gradually move from remote rural communities to progressively urban areas as opposed to pure distance measures of migration (Conway, 1980). In economics, neither geographic nor social measures of distance have been used extensively in empirical studies (Lucas, 2001). Published literature addressing migration in the Arctic is based primarily on publically available community level data.

Available Census micro-data allow us to uniquely test step-wise migration hypotheses in light of a standard household model of production. The remainder of this paper is organized as follows. The next section presents a short discussion of relevant literature and is followed by a discussion of relevant characteristics of the Arctic Alaska region. After that, we discuss a simple model of migration and present related empirical results in light of testable hypotheses.

\section{Background Literature}

The migration patterns we explore in this paper have been called by a variety of names: stepwise migration, hierarchical migration, stage migration, and chain migration (Conway, 1980). As noted, Ravenstein $(1885 ; 1889)$ first formalized observations of step-wise migration and noted that most moves are over short-distance. He observed that migration typically proceeds from smaller to larger communities as migrants from smaller communities fill-in gaps as migrants leave relatively larger places for places further up the hierarchy. A stepwise pattern of migration up the 
hierarchy is representative of US migration patterns through the 1950's. However, beginning in the 1970's a trend of 'counter-urbanization' replaced step migration in the US (Plane et. al., 2005).

At the same time, traditional hierarchical migration continues to describe migration patterns in many emerging market economies (Lucas, 2001) as well as in rural regions of industrial economies (Geib, 2001). In emerging market economies opportunities for both earnings and education are greater in larger urban areas resulting in movement up the hierarchy (Zhang, 2002). Others have shown that the development of social enclaves may facilitate migration. For some rural areas in the US, Geib (2001) argues that when controlling for social networks, transfer payments do not influence the decision to move within or between US reservation areas. That is, informal social safety nets and cultural ties are extremely important in the migration decision for Native Americans, even dampening the effects of transfer payments and other economic incentives. Similarly, a large literature within economic development has found that rural households in emerging market economies frequently rely on similar social networks or informal risk-sharing mechanisms to cope with unforeseen shocks (e.g., crop failure, sickness, or death) (Rosenzweig, 2001; Alderman and Paxson, 1994). Using data from rural India, Rosenzweig and Stark (1989) and Stark and Lucas (1988) link the migration decision to informal insurance mechanisms such as marriage customs that spread risk as families settle across wider geographic regions over time.

Lucas (2001) has also highlighted the role of distance as a determinant of hierarchical migration in developing countries. Distance affects the cost of a move (monetary, social, and psychic costs) which increases the potential for short moves. Close moves reduce social costs by reducing the cost of moving back. Movers close to the hierarchy may follow friends and relatives reducing social costs. Psychic costs might be reduced because places a bit larger are not that radically different from the place of emigration. Places not too far or too different from the place of emigration may have relatively similar economies which would allow work skills to be more easily transferred. Finally, Lucas (2001) suggests that close moves make it easier to return if the household faces a crisis in the new place.

In this paper we explore hierarchical migration while controlling for relative wages and unique personal and place characteristics such as subsistence hunting and fishing, an important activity among arctic Alaska's indigenous population. Because the regions we explore have increasing degrees of social distance we can also indirectly discuss the importance of social networks. To our knowledge, our test of hierarchical related migration hypotheses while controlling for wage and place characteristics, is unique to existing arctic migration literature. 


\section{The "Alaskan Arctic"}

For the purposes of this paper we define "arctic Alaska" as the three most northern census areas, the North Slope Borough, the Northwest arctic Borough, and the Nome Census area. These three census areas make up the historic Iñupiaq language grouping (Krauss, 1982) and the population is predominantly ethnic indigenous Iñupiat. ${ }^{1}$ Alaska's arctic region is a vast sparsely settled area. There are 146,000 square miles in the region settled by approximately 24,000 people who live in 35 different places. About $47 \%$ of the population lives in one of three regional centers, Barrow, Kotzebue, or Nome, while the remainder of the population lives in one of 32 villages that range in size from about 100 (Kobuk) to 750 (Point Hope) (US Census, 2000). Figure 1 provides a map of the region.

\section{Figure 1. Map of "arctic Alaska."}

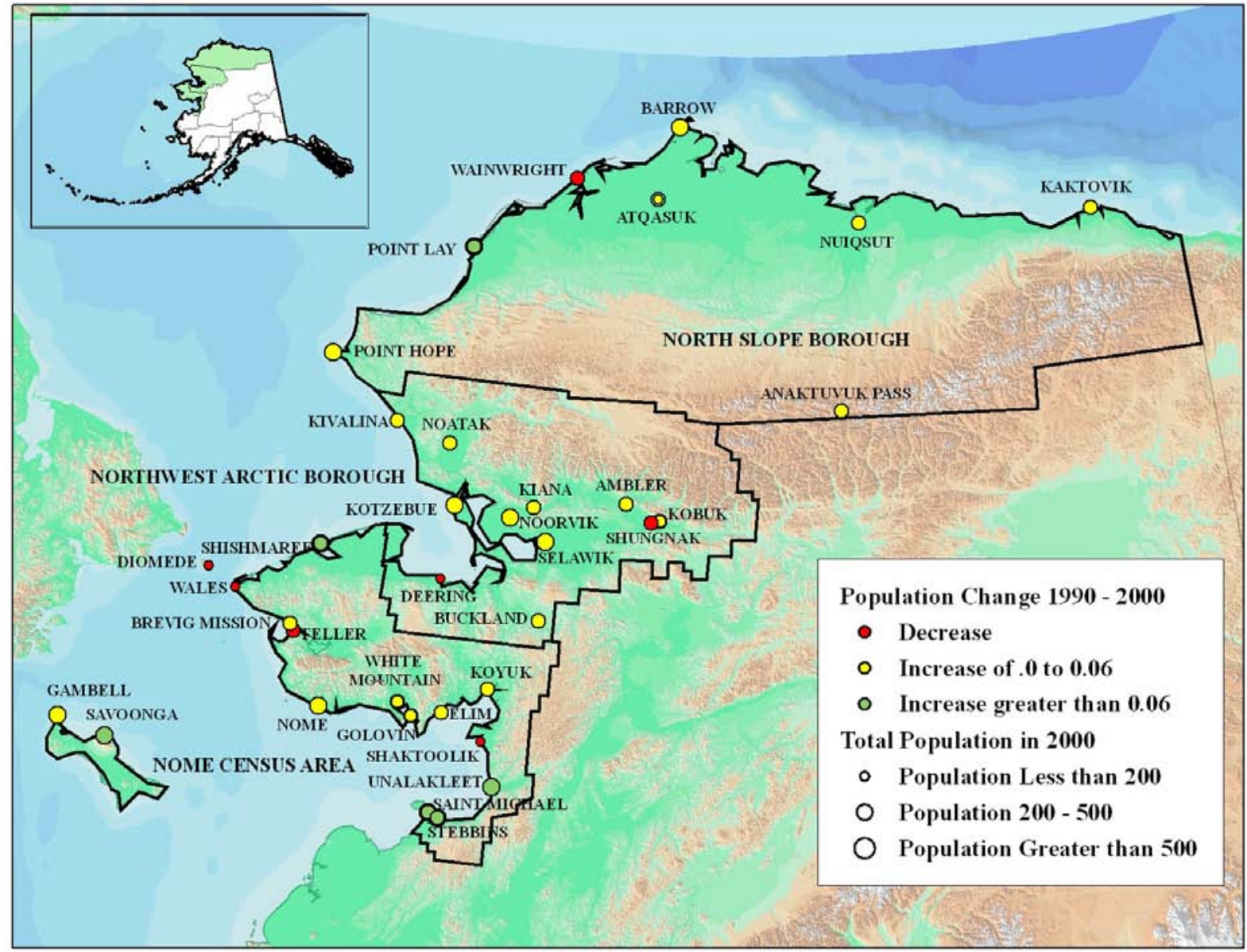

The region lacks significant road connections and travel to and from communities within and outside of the region is costly. Movement to and from regional centers is typically by small aircraft and in the winter people travel by snow machine or truck on ice roads.

\footnotetext{
${ }^{1}$ Overall, about $80 \%$ of the population self-identifies as Alaska Native - in the 32 arctic villages about $90 \%$ of the population selfidentifies as Alaska Native (US Census, 2000).
} 
In terms of migration, general patterns have changed dramatically over the past fifty years. From the 1950's to the 1970's dominant out-migration from villages to larger urban areas prevailed as migrants sought out better place amenities and infrastructure (Alonso and Rust, 1976). Almost half of the places in the north and the west of Alaska had 100 or fewer people in 1950 and there were only two places with population over 1,500. By 1970 less than one-third of these places had populations less than 100, there were 6 places with populations greater than 1,500, and the number of villages fell by $7 \%$ (Alonso and Rust, 1976).

In the 1970's large out-migration subsided. Kruse and Foster (1986) found that regionalization slowed as in-migration to remote villages increased from urban areas and the larger rural communities. They also found that non-Natives made up a growing share of migrants to arctic places.

For the 1980's and 1990's Howe (2009) found high rates of migration to and from villages and patterns that appeared consistent with hierarchical migration. In arctic villages, population generally flowed out to regional centers at greater rates compared to other regions. Movers from regional centers moved at greater rates to urban areas compared to other destinations. Also, movers from large urban areas moved to out of state destinations at greater rates compared to alternative destinations. At the same time, there was sizeable return migration that seemed to follow the same general hierarchical pattern. Similar to Kruse and Foster (1986), Howe (2009) found that there is significant return migration to arctic places from urban and semi-urban regions.

Opportunities in both the formal and informal economy are important drivers of arctic migration patterns. Like many rural economies, Alaska's arctic economy is a mixed subsistence and cash economy. Frequently cash earned in formal labor markets is used to purchase goods and services in other markets but cash also serves as an important input to harvesting subsistence resources.

Harvesting and consuming subsistence resources, such as marine mammals, fish, caribou, and other land mammals, is an extremely important component of life in arctic Alaska. In villages, about $70 \%$ of households reported participating in subsistence harvests while in regional centers about $60 \%$ of households participated (SLiCA, 2003). The state of Alaska has estimated that about $50 \%$ of total caloric needs are met through subsistence consumption in our study area (ADFG, 2000). Over time the importance of cash has increased. Dog teams have been replaced with snow machines, motorized boats and other modern hunting gear (e.g., ropes, rifles, and nets) are a necessity in fishing and marine mammal hunting. Given its fundamental importance in daily life, subsistence considerations also play an important role in the decision to migrate.

In terms of the formal economy, the employment opportunities are influenced heavily by federal transfers and public sector hiring. In the late 1990's transfer payments made up about 28\% of total personal income in the Northwest arctic Borough, 25\% in the Nome Census area, and 12\% 
in the North Slope Borough (BEA, 2007). ${ }^{2}$ In addition, direct public sector hiring accounts for more than 42 percent of employment in the combined arctic region. The impact of public spending is even greater when the non-profit agency spending is included.

Mining and oil field services are also important drivers of the cash economy in the Arctic. While very few arctic Alaska residents are directly employed in oil field services, a significant share of North Slope Borough public sector income comes from tax revenue collected from North Slope production facilities at Prudhoe Bay. In 2003, tax receipts from oil production facilities accounted for about 68\% of the North Slope Borough's income (about \$198 million). In the Northwest arctic Borough about 75\% of the Borough's general fund income (about $\$ 6.2$ million) comes from the Red Dog zinc mine. Local employment in the Northwest arctic mine of Red Dog is more common than oil field services employment; about $56 \%$ of the mines contractors and workers are originally from the Northwest arctic Borough.

While there is some variation across regions, formal sector opportunities are limited and unemployment is higher in the Arctic compared to the rest of Alaska. In 2003 the state's unemployment rate was $8 \%$ while it was $13.8 \%$ in the NSB, $15.2 \%$ in the Nome region, and $20.1 \%$ in the Northwest arctic Borough (AKDOL, 2005). This has been a relatively long run pattern as real rates of unemployment are actually much higher in these small regions where many working age adults sit out of the labor force until they know jobs are available.

Income per capita is also lower and poverty rates are higher in the Arctic region compared to Alaska's urban centers. In 2004 per capita income was estimated to be $\$ 37,750$ in Anchorage, the state's largest city. Per capita income in the North Slope Borough was slightly less than this at $\$ 36,613$. The other two regions have significantly lower per capita incomes of around $\$ 25,000$. arctic regions also had higher rates of poverty among households than in Anchorage; in 2000 approximately $6.4 \%$ of Anchorage households fell below the poverty line compared to $10 \%$ in the North Slope Borough and around $20 \%$ in the other two arctic regions. Since there is only one poverty line for Alaska the large differences in food and fuel costs are not reflected in poverty measures. Robinson and Fried (2005) estimated food costs relative to Anchorage to be $80 \%$ more in Nome and $150 \%$ more in Barrow.

Like most rural economies, however, the significance of income differences is diminished by the relative importance and availability of subsistence. Below we include both relative wages and relative subsistence in a model of migration.

\footnotetext{
2 BEA (2007) defines transfers as payments to individuals by state or federal government for which no service is performed. Transfers include retirement and disability insurance benefits, medical benefits, income maintenance benefits (e.g., food stamps), unemployment insurance benefits, veterans' benefits, and Federal education and training benefits (e.g., grants and subsidized loans to students).

Transfers also include Alaska Permanent Fund dividend payments (PFD) which were first distributed in 1982. The average annual PFD dividend was $\$ 1,449$ per person from 1995 to 2000.
} 


\section{Data and Methods}

\section{Background analytical model}

Migration in our model is motivated by a standard result from a household production model of migration (Huskey, Berman, and Hill, 2007; Singh, Squire, and Strauss, 1986). Migration from place $A$ to $B$ occurs if individual utility in place B, net of migration costs, is greater than utility of other destination possibilities,

$$
U_{i A}<U_{i B}-C_{i B}
$$

Utility in place $\mathrm{j}$ is a function of market goods consumed $\left(X_{\text {im }}\right)$, leisure enjoyed $\left(t_{i l}\right)$, place characteristics $\left(P C_{j m}\right)$, and harvest of subsistence resources, $S\left(t_{i s}, X_{i s}, P C_{j s}\right)$, which is a function of time spent doing subsistence $\left(t_{i s}\right)$, market inputs to subsistence $\left(X_{i s}\right)$, and subsistence related place characteristics $\left(P C_{j s}\right)$,

$$
U_{i j}=f\left(X_{i m}, S\left(t_{i s}, X_{i s}, P C_{j s}\right), t_{i l}, P C_{j m}\right)
$$

The household's budget's constraint reflects that expenditures equal income (there is no savings or debt),

$$
P_{m} X_{i m}+P_{s} X_{i s}=w_{m} t_{i m}
$$

and time is fully allocated across working in the formal labor market for cash, harvesting subsistence resources, and enjoying leisure,

$$
t_{i m}+t_{i s}+t_{i l}=T
$$

Maximizing utility subject to (2) and (3), we find that households allocate labor across market activities, subsistence, and leisure such that marginal utilities are equal across the three activities. Related first order conditions include:

$$
\begin{aligned}
& \frac{d L}{d X_{i m}}: \frac{d U}{d X_{i m}}-\lambda_{1}\left(P_{m}\right)=0 \\
& \frac{d L}{d X_{i s}}: \frac{d U}{d X_{i s}} \frac{d S}{d X_{i s}}-\lambda_{1}\left(P_{s}\right)=0 \\
& \frac{d L}{d t_{i m}}: \lambda_{1} w_{m}-\lambda_{2}=0 \\
& \frac{d L}{d t_{i s}}: \frac{d U}{d t_{i s}} \frac{d S}{d t_{i s}}-\lambda_{2}=0 \\
& \frac{d L}{d t_{i l}}: \frac{d U}{d t_{i l}}-\lambda_{2}=0
\end{aligned}
$$


where $\lambda_{1}$ is the Lagrange multiplier on constraint (2) and $\lambda_{2}$ is the multiplier on constraint(3). Simplifying the above, we see that utility is maximized when time is allocated in location $\mathrm{j}$ such that marginal utilities are equal across activities:

$$
\frac{d U}{d X_{i m}} \frac{w_{m}}{P_{m}}=\frac{d U}{d X_{i s}} \frac{d S}{d X_{i s}} \frac{w_{m}}{P_{s}}=\frac{d U}{d t_{i s}} \frac{d S}{d t_{i s}}=\frac{d U}{d t_{i l}} .
$$

In each location labor is allocated in such a way as to maximize utility and it is clear that regional differences in place amenities $\left(P C_{j s}, P C_{j m}\right)$ are important drivers of migration in the model. All else equal, in places with relatively good place characteristics $\left(P C_{j m}\right)$ such as low crime rates, quality schools, or closed pipe water and sewer systems, labor will be allocated in the same way as in cities with different place characteristics but utility will be relatively higher. In contrast, in places with different subsistence opportunities $\left(P C_{j s}\right)$ or different real wage rates $\left(\frac{w_{m}}{P_{m}}, \frac{w_{m}}{P_{s}}\right)$ time allocation will change.

This basic household production model suggests that, holding all else constant, increases in real wages (wages with respect to the price of market goods and the price of subsistence goods) increase the probability of migration. Similarly, greater prospective utility in an alternative destination due to relatively better place characteristics $\left(P C_{j s}\right.$ or $\left.P C_{j m}\right)$ suggests a greater probability of migration in the model. Last, reduced costs of migration to an alternative destination $\left(C_{i j}\right)$ also suggest a greater probability of migration.

Often relative values of $P C_{j s}, P C_{j m}, \frac{w_{m}}{P_{m}}$, and $\frac{w_{m}}{P_{s}}$ may run in opposite directions. For instance, a migrant leaving a remote village to an urban area is leaving a place with a relatively high $P C_{j s}$ but with relatively low $\frac{w_{m}}{P_{m}}$ and possibly a low $P C_{j m}$. That is, subsistence place characteristics are excellent but real wages and other place characteristics are relatively poor. Similarly, the model suggests that relative $P C_{j s}$ is a key factor in a migrant's decision to leave an urban area for a remote rural village.

The empirical model outlined below, a mixed multinomial choice model, allows us to test the extent to which relative wages, subsistence, and a limited set of place amenities influence the probability of migration from one destination to another. The model accounts for alternative specific variables (e.g., predicted wages and subsistence place characteristics) and place invariant individual and household characteristics (e.g., age and household size) that are important components of the migration decision. However, because of data limitations we don't explore the effects migration costs in the empirical model. The model is estimated on the set of Alaska Native movers from six different geographic regions. Prior to presenting the empirical model, we briefly describe data used in the estimation. 
Data used in the regressions is primarily from the 2000 US Decennial Survey of Population and Housing. These micro data were accessed at a secure US Census Center for Economic Studies (CES) Research Data Center (RDC) at the University of California, Los Angeles. ${ }^{3}$ The micro-data include long-form and short-form responses for the entire universe of US Census respondents. The data reported in this paper were screened to ensure that no confidential information was inadvertently disclosed. ${ }^{4}$

Decennial Census data include long form responses on the place of residence five years prior to the 2000 Census. Related responses were used to identify all Alaska Native respondents living in the US, and members of their households, who reported living in the Arctic in 1995. Model estimates were made on the set of Alaska Native respondents and their households currently living in arctic Alaska in addition to Alaska Native households living in another US state who reported living in Alaska five years previously.

While these data provide an excellent picture of migration, as with all survey data there are several sources of error. Data on income, migration, education and other personal characteristics are based on long form questions which were administered to about $50 \%$ of rural Alaska households. In urban areas and in the rest of the United States about $20 \%$ of households received a long-form survey. Error is also introduced through imputations and substitutions for nonresponse. In some cases, surveys were not complete or information was inconsistent and the Census used substitutions or a hot-deck type imputation procedure to generate estimates for missing data. As we will discuss, we excluded imputed cases for certain variables in the regressions (e.g., migration and income).

\section{Earnings and Subsistence Predictions}

As mentioned, the migration model accounts for predicted earnings and predicted subsistence. To predict earnings we use a two step process. In the first step, the log of individual wages for Alaska Native respondents with positive earnings is regressed on a vector of individual characteristics,

$$
\ln \left(w_{i j}\right)=\beta_{0}+\beta_{1} X_{i}^{1}+u_{i}
$$

\footnotetext{
${ }^{3}$ More information about the program is here: http://www.census.gov/ces.

${ }^{4}$ Any opinions and conclusions expressed herein are those of the author(s) and do not necessarily represent the views of the U.S.

Census Bureau.
} 
for regions $j=1, \ldots, 6$ where $X_{i}^{1}$ is a vector of place invariant individual characteristics. Estimates are made for each region ( $j$ ) and associated coefficients are used in the second step to predict earnings in each region for all Alaska Native respondents 16 years of age and older. ${ }^{5}$

Based on equation (1), we predict wages for all individuals in each of the six geographic regions (i.e., $j=1, \ldots, 6$ ). The regional grouping designated "arctic villages" is made up of the 32 arctic villages shown in Figure 1 and "arctic regional centers" is made up of the three regional centers Barrow, Kotzebue and Nome. "Anchorage" is made up of the Anchorage municipality (which includes the cities of Eagle River and Girdwood) and all places in the Mat-Su Borough. "Other Rural Alaska" is made up of rural census districts besides places in the Arctic, and "other Urban" is made up of all other Alaska Census Areas including the Fairbanks North Star Borough. "Other State" includes Alaska Native respondents who lived in arctic Alaska in 1995 but in another US State in 2000 . We predict wages for all 6 regions. ${ }^{6}$

In the second step of the earnings predictions average hours worked per week in each region is regressed on a vector of individual, household, and regional characteristics. A censored regression is used where hours worked are censored at 0 and a maximum of 60 hours per week. Predicted wages from the first step are included as a proxy for human capital. The equation to be estimated is,

$$
h_{i j}=\beta_{0}+\beta_{1} X_{i}^{2}+\beta_{2} i \hat{w}_{i j}+\beta_{3} H_{i}+\beta_{4} R_{j}+u_{i}
$$

which was run separately for regional locations $j=1, \ldots, 6$. As above, $X_{i}^{2}$ is a vector of individual characteristics (different from $X_{i}^{1}$ ), $H_{i}$ household characteristics, $R_{j}$ regional characteristics, and $\hat{w}_{i j}$ is the individual predicted wage assuming residence in region $\mathrm{j}$. Regional characteristics are equal to the characteristics for a particular place at the origin and for prospective destinations (i.e., regions 1 to 6 are the possible destinations) regional characteristics are equal to the average of place characteristics for each region. Predicted earnings for each of the six regions are therefore the product of the hours worked predictions from equation (4) and wage predictions from equation (5) for all Alaska Native adults 16 and older in the sample (i.e., $\hat{h}_{i j} \times v \hat{w}_{i j}$ for $\left.\mathrm{j}=1, \ldots, 6\right)$.

Individual subsistence harvest data used in our regressions is produced using a prediction model estimated by Berman (2009). In his model, a Tobit specification is used to estimate household subsistence production based on a vector of individual, household, and subsistence relevant place characteristics,

$$
s_{i j}=\beta_{0}+\beta_{1} X_{i}+\beta_{2} H_{i}+\beta_{3} P C_{j s}+u_{i}
$$

\footnotetext{
${ }^{5}$ Actual wages, $\mathrm{w}_{\mathrm{ij}}$, are derived by dividing total annual wage and salary earnings by average hours worked per year. 
Data used in Berman's (2009) estimates is from The Survey of Living Conditions in the Arctic (SLiCA), a household survey of arctic villages in our study region. ${ }^{7}$ Our subsistence predictions are made using Berman's estimated coefficients on the corresponding set of independent variables. ${ }^{8}$ SLiCA gathered individual and household information from one adult respondent in each housing unit, consequently Berman's (2009) estimates are household predictions based in part on the characteristics of randomly selected adult respondent. Similarly, in applying Berman's estimates to our data we randomly select an adult from each housing unit in the Census data and predict household level subsistence based on that adult's personal characteristics along with the characteristics of others in the housing unit. The same household subsistence prediction is applied to everyone living in the housing unit.

\section{Migration predictions}

To predict migration probabilities from region A to a set of alternative regions, we use a mixed multinomial and conditional logit model that accounts for alternative specific characteristics (such as predicted earnings and subsistence) and fixed characteristics (such as age and gender). The multinomial model normally assigns regression coefficients across alternatives for place invariant independent variables (e.g., age and gender) and the conditional logit model assigns a single coefficient for place variant independent variables (e.g., subsistence and earnings) (Cameron and Trivedi, 2005). The mixed model combines alternative specific regressors from the conditional logit model with fixed characteristics of the multinomial logit model. ${ }^{9}$

The mixed model we estimate is

$$
y_{i j}=\beta_{S} S_{i j}+\beta_{E} E_{i j}+\alpha_{j}+\beta_{A j} A_{i}+\beta_{H j} H_{i}+\varepsilon_{i}
$$

where $\mathrm{S}$ denotes predicted subsistence harvest, E predicted earnings, $\mathrm{A}$ is a vector of individual characteristics, $\mathrm{H}$ is a vector of household characteristics, and subscript $\mathrm{j}$ denotes alternative destinations. In this model we have a set of unordered alternatives (j), which are migration destinations $(j=1, \ldots, 6)$, and individual $i$ is choosing between the different destinations; if individual i chooses alternative $\mathrm{j}, y_{i j}=1$, otherwise $y_{i j}=0$. As indicated, the alternative specific regressors that vary across alternatives include subsistence $(S)$ and earnings $(E)$, and as in the conditional logit model respective regression coefficients don't vary across alternatives. Invariant alternatives include individual characteristics (A) and household characteristics $(\mathrm{H})$, hence

\footnotetext{
${ }^{7}$ More information about SLiCA can be found here http://www.arcticlivingconditions.org/

${ }^{8}$ Appendix 1 presents Berman's estimates used in our predictions. Individual characteristics in the model were gender, age, education, disability status, and ability to speak a Native language. Household characteristics included number of adult females, number of adult males, number of teens 16 and older, number of non-Natives in the household, an indicator if there are no men in the household (binary), number of children under 16, the number of children under 5, an indicator if it a household with a single female and children (binary). Regional variables included weighted regional employment in 2000, change in regional employment between 1995 and 2000 , an indicator for the regional center (binary), an indicator if the community is coastal (binary), an indicator if the community is in proximity to caribou hunting (binary), and an indicator if the community is in proximity to salmon fishing (binary).

${ }^{9}$ Note that this model differs from the random utility "mixed model" as described in McFadden and Train (2001).
} 
corresponding regression coefficients vary across alternatives as they do in the standard multinomial logit model with alternative invariant characteristics.

In the mixed model, individual i's probability of moving to destination $\mathrm{j}$ can be written as,

$$
p_{i j}=\operatorname{Pr}\left[y_{i}=j\right]=\frac{\exp \left(\beta_{S} S_{i j}+\beta_{E} E_{i j}+\alpha_{j}+\beta_{A j} A_{i}+\beta_{H j} H_{i}\right)}{\sum_{k=1}^{5} \exp \left(\beta_{S} S_{i k}+\beta_{E} E_{i k}+\alpha_{k}+\beta_{A k} A_{i}+\beta_{H k} H_{i}\right)}, \mathrm{j}=1,2, \ldots, 5
$$

where subscripts $\mathrm{j}$ or $\mathrm{k}$ denote alternative destinations. As indicated in (8), this probability equation simply combines components of the conditional and multinomial logit models.

Our analysis is only on respondents who are "stayers" or respondents who move within a meta-region since our focus is on identifying patterns of migration and determinants of migration for movers. Also, given our modeling approach, by focusing only on movers, we avoid combining alternatives that may not be independent.

In multinomial models the odds ratio of any two alternatives are assumed to be independent of other alternatives (i.e., the independence of irrelevant alternatives). As such, if place $A$ is preferred to place $B$ this relation should hold irrespective of the alternatives added to the model. Independence of irrelevant alternatives also implies that the odds ratio between destination A and destination B should be constant regardless of the addition of destination C. Constant relative odds may make sense between different migration destinations but it seems problematic when a stay option is added as an alternative. In arctic regions upwards of $50 \%$ of the population choose to "stay." It seems more appropriate to either model the stay and move decisions in nested logit framework or just to focus the multinomial choice model on movers. In the current paper we choose the latter approach, hence we exclude "stayers" from our analysis.

\section{Results}

We begin by discussing general results of the labor market equations and conclude with findings based on the migration regressions.

\section{Labor market equations}

Estimates from the hourly wage regressions described in equation (1) are presented in Table 4 of the appendix. As indicated, personal characteristic variables are generally significant in the wage regressions. Diminishing returns to wages with age is common across all regions (see age and agesq). Also, in every region females earn significantly less than men, the difference is about $10 \%$ in villages, $17 \%$ in regional centers, and $30 \%$ in Anchorage. Across regions higher education is 
associated with higher wages, Alaska Natives with a BA degree make about $60 \%$ more in arctic regional centers and $34 \%$ more in arctic villages compared to people with less than a high school degree.

Hours worked regressions based on equation (5) are presented in Table 5 of the appendix. Predicted wages for the six regions are included as a proxy for human capital along with a different set of individual and household characteristics. Predicted hours worked were made for all Alaska Native respondents 16 years and older irrespective of current labor force participation. As expected, predicted wages are a robust indicator of hours worked - an increase in wages of $\$ 1 /$ hr increases hours worked by about 95 hours per year in arctic villages and Regional Centers. "Female" has a mixed effect on hours worked across locations, increasing hours worked in arctic villages while decreasing hours worked in other locations. ${ }^{10}$

Household characteristics have mixed effects on hours worked. Individuals from large households $(n>5)$ are predicted to work fewer hours than smaller households. Households made up of a single mother with children work more hours in arctic places than individuals from other households types but fewer hours in other geographic regions. ${ }^{11}$

Place characteristics in Table 5 include change in employment, weighted total employment, and dummy variables for coastal places, places where caribou are harvested, and places where salmon are harvested. When significant, the effect of coastal, caribou, and salmon on hours worked in the formal labor market is generally negative. The exception is living in an arctic village where caribou can be harvested. In arctic villages, "caribou" has the effect of increasing predicted hours worked possibly reflecting Northwest arctic villages that are in proximity to the Red Dog mine. In those villages, caribou hunting is possible and formal labor market opportunities are less scarce compared to other villages. In other regions, the negative sign on subsistence characteristics signals that subsistence time may trade off with participation in the formal labor market as subsistence opportunities improve.

\section{$\underline{\text { Hierarchical migration }}$}

Predicted hours worked and wages are multiplied to generate predicted earnings for Alaska Natives 16 and older. Predicted subsistence and predicted earnings are then used in estimating equation (7), the multinomial mixed model. The mixed model was run with place variant characteristics (predicted earnings and predicted subsistence) and place invariant dummy variables (female, youth, elder, solo household, large household, and married couple household),

\footnotetext{
${ }^{10}$ This is consistent with the fact that female labor force participation rates are relatively greater in many arctic villages compared to other Alaska locations.

${ }^{11}$ This may be due in part to a larger social network in arctic places which would reduce the opportunity costs of outside employment for single parents.
} 
odd ratios are shown in Table 6 of the appendix. ${ }^{12}$ Coefficients of the place invariant variables are relative to the base category, migration to another US state. We also ran the multinomial model with different place invariant characteristics (female and Inupiat) but the same place variant characteristics. Results of these regressions are presented in Table 8 of the appendix. ${ }^{13}$

To explore specific hypotheses related to hierarchal migration we calculate probabilities as indicated in equation (8). Probabilities associated with moving out from an arctic village, an arctic regional center, Anchorage, or another Rural Alaska area, are provided in Table 1 and Table 2 Table 1 presents probabilities associated with the estimates provided in Table 6 of the appendix and Table 2 presents probabilities from a model that limits place invariant characteristics to female and Iñupiat (Table 8. of the appendix).

\footnotetext{
12 The odds ratio (or relative-risk ratio) provides information the probability of choosing destination $\mathrm{j}$ relative to some other alternative (k in this example) when $x_{i}$ changes by one unit, $\frac{P\left(y_{i}=j\right)}{P\left(y_{i}=k\right)}=e^{x_{i} \beta_{j}}$.

${ }^{13}$ Including "Inupiat" allows us to predict Iñupiat migration for Alaska Natives leaving the Anchorage region as well as other Rural and Urban areas. We ran separate regressions because convergence was a problem when including "Inupiat" with the full set of place invariant characteristics.
} 
Table 1. Choice of migration destinations: predicted migration probabilities (based on coefficients in Table 6.)*

\begin{tabular}{|c|c|c|c|c|c|}
\hline & & \multicolumn{4}{|c|}{ Origin } \\
\hline & & Villages & Regional Centers & Anchorage & Other Rural \\
\hline & Males and Females & & & & \\
\hline \multirow{7}{*}{$\begin{array}{l}\underset{0}{0} \\
\stackrel{0}{0} \\
\stackrel{0}{\Xi} \\
\stackrel{0}{0}\end{array}$} & Rural & 0.0017 & 0.0407 & 0.1578 & \\
\hline & Villages & & 0.1794 & 0.0387 & 0.0092 \\
\hline & Regional Centers & 0.4901 & & 0.0309 & 0.0055 \\
\hline & ANC & 0.4590 & 0.5946 & & 0.5683 \\
\hline & Fair / other urban & 0.0005 & 0.0845 & 0.1872 & 0.2994 \\
\hline & Other US & 0.0487 & 0.1007 & 0.5855 & 0.1175 \\
\hline & Females & & & & \\
\hline \multirow{7}{*}{ 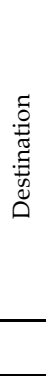 } & Rural & 0.0010 & 0.0470 & 0.1876 & \\
\hline & Villages & & 0.2008 & 0.0325 & 0.0072 \\
\hline & Regional Centers & 0.3719 & & 0.0437 & 0.0051 \\
\hline & ANC & 0.5772 & 0.6006 & & 0.5719 \\
\hline & Fair / other urban & 0.0006 & 0.0840 & 0.1835 & 0.2789 \\
\hline & Other US & 0.0494 & 0.0676 & 0.5526 & 0.1368 \\
\hline & Males & & & & \\
\hline \multirow{6}{*}{ 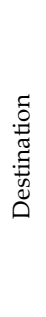 } & Rural & 0.0031 & 0.0340 & 0.1279 & \\
\hline & Villages & & 0.1549 & 0.0464 & 0.0128 \\
\hline & Regional Centers & 0.6243 & & 0.0206 & 0.0059 \\
\hline & ANC & 0.3278 & 0.5749 & & 0.5590 \\
\hline & Fair / other urban & 0.0003 & 0.0830 & 0.1888 & 0.3277 \\
\hline & Other US & 0.0445 & 0.1530 & 0.6163 & 0.0945 \\
\hline
\end{tabular}


Table 2. Choice of Iñupiat migration destinations: predicted migration probabilities (based on coefficients in Table 8.)*

\begin{tabular}{|c|c|c|c|c|c|}
\hline & & \multicolumn{4}{|c|}{ Origin } \\
\hline & & Villages & Regional Centers & Anchorage & Other Rural \\
\hline & Males and Females & & & & \\
\hline \multirow{7}{*}{ 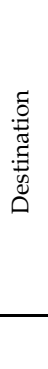 } & Rural & 0.0084 & 0.0281 & 0.0733 & \\
\hline & Villages & & 0.2169 & 0.2941 & 0.1277 \\
\hline & Regional Centers & 0.5258 & & 0.2514 & 0.0330 \\
\hline & ANC & 0.3419 & 0.6205 & & 0.4645 \\
\hline & Fair / other urban & 0.0981 & 0.0827 & 0.1557 & 0.3748 \\
\hline & Other US & 0.0259 & 0.0518 & 0.2255 & 0.0000 \\
\hline & Females & & & & \\
\hline \multirow{7}{*}{ 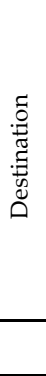 } & Rural & 0.0046 & 0.0298 & 0.0847 & \\
\hline & Villages & & 0.2068 & 0.2288 & 0.1092 \\
\hline & Regional Centers & 0.4093 & & 0.3264 & 0.0330 \\
\hline & ANC & 0.4338 & 0.6370 & & 0.4924 \\
\hline & Fair / other urban & 0.1226 & 0.0837 & 0.1491 & 0.3655 \\
\hline & Other US & 0.0297 & 0.0426 & 0.2110 & 0.0000 \\
\hline & Males & & & & \\
\hline \multirow{6}{*}{ 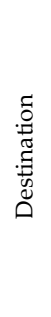 } & Rural & 0.0153 & 0.0263 & 0.0594 & \\
\hline & Villages & & 0.2277 & 0.3730 & 0.1572 \\
\hline & Regional Centers & 0.6514 & & 0.1790 & 0.0329 \\
\hline & ANC & 0.2420 & 0.6007 & & 0.4251 \\
\hline & Fair / other urban & 0.0707 & 0.0813 & 0.1563 & 0.3849 \\
\hline & Other US & 0.0206 & 0.0640 & 0.2322 & 0.0000 \\
\hline
\end{tabular}

\section{Result \#1: Stepwise migration up the hierarchy is observed}

Overall, controlling for predicted wages, subsistence, and personal characteristics the probability of moving to an arctic regional center is greater from an arctic village compared to any other origin. This result is robust across men and women. Similarly, people who leave an arctic regional center are more likely to move one-step up the hierarchy (e.g., to Anchorage) compared to a two-step move (e.g., out of state) or a move down the hierarchy. Also, the probability of moving out of state is greater from Anchorage compared to any other starting point.

For movers leaving an arctic village, the probability of migrating to an arctic regional center was greater compared to other locations (49\% in Table 1 and 52\% in Table 2). By gender, however, these stepwise patterns differ. For Iñupiat men, the probability of migration to a regional center from a village is much greater than the probability of moving to Anchorage $(0.65>0.24$, Table 2 ). Iñupiat women, however, are equally likely to move from an arctic village to a regional center 
or directly to Anchorage $(0.41 \approx 0.43$, Table 2$)$. Marginal fixed effects not restricted to just Inupiat people, but includes all Alaska Native people, indicates that being female increases the probability of migration from villages to Anchorage whereas it reduces the probability of migration from arctic villages to Regional Centers.

For migrants leaving arctic regional centers the probability of moving directly to Anchorage is much greater than for any other location (60\% in Table 1 and $62 \%$ in Table 2). This prediction is about the same for men and for women. Also, compared to outmigration from villages, the probability of moving to Anchorage is much greater from regional centers as compared to villages or "other rural" destinations. Similarly when Inupiat people leave "other rural" areas in Alaska, which in include villages and regional centers in other areas (e.g., Bethel and Dillingham), the greatest probability is a move to Anchorage followed by a move to Fairbanks/ other urban (Table 2). Results for men and women are consistent.

In terms of out of state migration, the evidence is generally consistent with hierarchical migration. In both Table 1 and Table 2 the probability of moving to another US State is greater from Anchorage, the most urbanized area, compared to any other origin; this holds for both men and women. In addition, for Alaska Native movers (Table 1) leaving Anchorage they are more likely to go to an out of state destination compared to any other destination. In contrast, for Iñupiat movers (Table 2) leaving Anchorage they are more likely to go to either an arctic village (29\%) or an arctic regional center (22\%) relative to an out of state destination (23\%).

\section{Result \#2 Relative earnings is an important driver of migration from arctic villages but not from other locations.}

Odds ratios on earnings, presented in Table 6 of the appendix, indicate the probability of choosing a region with $\$ 1$ higher relative earnings. Only in the case of out-migration from villages is the coefficient significant. Marginal fixed effects, $\left(\frac{\partial p_{i j}}{\partial x_{i}}\right)$, shown in Table 7 of the appendix provide more information on the effect of earnings. They indicate that a relative increase of $\$ 1000$ in predicted earnings increases the probability of moving from an arctic village to a regional center by $6.3 \%$, from an arctic village to Anchorage by about $6.2 \%$, from an arctic village to another rural location by about $0.044 \%$, and from an arctic village another US place outside of Alaska by $1.2 \%$.

For migrants leaving arctic regional centers, a $\$ 1,000$ increase in income doesn't significantly influence the probability of migrating to Anchorage (at 10\%). This holds for women and men and for Iñupiat and all Alaska Native migrants. A similar result holds for outmigration from Anchorage or other rural locations; an increase in predicted earnings doesn't significantly 
influence the probability of leaving Anchorage. This suggests that factors other than earnings are particularly important in the decision to move down the hierarchy.

\section{Result \#3 When moving down the hierarchy, subsistence is an important determinant of migration}

Relative to earnings, predicted subsistence is a more important determinant of migration when moving to a region with relatively more subsistence. The odds of migration increase as subsistence increases when moving from "other rural origin" to a destination with relatively more subsistence opportunities than other alternatives (Table 6). Similarly for out-migration from Anchorage back to the Arctic, there is a large and significant increase in the probability of migration to a place with increasing relative subsistence opportunities. In general, better subsistence opportunities appear to increase the probability of movement down the hierarchy.

In the other direction, movement up the hierarchy, subsistence doesn't appear to be important when the origin is already a high subsistence producing region. For instance, for both arctic villages and arctic regional centers subsistence is not an important determiner of the location a migrant chooses.

Marginal fixed effects indicate that a 10\% relative increase in subsistence opportunities increases the probability of moving from Anchorage to an arctic villages by around $4.4 \%$ (significant at 1\%) (Table 7). A relative increase in predicted subsistence of $10 \%$ in arctic regional centers increases the probability of moving from Anchorage to regional centers by about 3.5\% (significant at $1 \%$ ). The effect of subsistence on the probability of moving up the hierarchy is minimal. In terms of migration from Villages to Regional Centers and from Regional Centers to Anchorage, we can't reject the null hypothesis that the marginal effect of subsistence is zero. This is consistent with the fact that relative subsistence opportunities generally decline as one moves up the hierarchy.

\section{Result \#4. Hierarchical migration patterns vary by individual characteristics}

Migration patterns also differ by other place invariant characteristics such as age, size of the household, and household type. This is evident from odds ratios in Table 6. Table 6 shows odds ratios for all regions relative to the out of state alternative.

In leaving arctic villages, for instance, "elders" are much more likely than non-elders to move from an arctic village to a regional center or to Anchorage compared to an out of state alternative. ${ }^{14}$ "Youth" living in an arctic village are significantly less likely than other ages to

\footnotetext{
${ }^{14}$ A difference in means test indicates differences between Anchorage and Regional Centers aren't significant.
} 
choose an "other urban" location compared to the out of state choice. Relative to other household types, single person households (solohh) and large households (bighh) are much less likely to move to other rural locations compared to the out of state category. Also, compared to other age groups, elders moving back to the Arctic are more likely to move to a village relative to a regional center $(\mathrm{t}=7.66)$.

Marginal fixed effects indicate that being from a married household reduces the probability of moving from arctic regional centers to Anchorage (by 0.28). Being Inupiat increases the probability of moving from Anchorage to Villages (by 0.28 ) and similarly of moving from Anchorage to Regional Centers (by 0.24). Being Iñupiat also reduces the probability of moving from Anchorage to another US State (by 0.39).

\section{Result \#5: Step-wise migration down the hierarchy differs between men and women.}

Evidence of gender differences in step-wise migration down the hierarchy is mixed. If a stepwise pattern of migration down the hierarchy were representative of migration patterns then we should observe a relatively greater probability of migration from urban to rural compared to migration from urban to remote rural.

Iñupiat migrants who leave Anchorage for an arctic location are about equally likely to go to villages or to arctic regional centers over other destinations (Table 2). Iñupiat women leaving Anchorage, however, are most likely to choose an arctic regional center (33\%) while Iñupiat men are more likely to choose an arctic village (37\%) over other destinations. Marginal fixed effects also indicate significant differences between Iñupiat men and women in migration from Anchorage to villages and regional centers.

\section{Conclusion}

In this paper we explore evidence for hierarchical migration patterns among Alaska Native residents of arctic Alaska. We predict earnings and subsistence for adults over 16 and use these predictions in a multinomial logit model to calculate migration probabilities to and from the Arctic. Estimated probabilities are used to test hypotheses related to hierarchical migration.

First we highlight evidence consistent with step-wise migration up a hierarchy. Controlling for predicted income and subsistence across places and individual and household characteristics we find that Iñupiat people are more likely to move up one level in a step-wise hierarchical fashion - from an arctic village to an arctic regional center and from an arctic regional center to Anchorage. We also noted that Iñupiat migrants living in Anchorage are more likely to move to another State 
compared to Inupait migrants living in arctic villages, arctic regional centers, or other rural parts of Alaska.

In terms of migration down the hierarchy, the evidence is mixed. Iñupiat men are more likely to go from Anchorage to an arctic village compared to an arctic regional center while Inupait women are more likely to go from Anchorage to an arctic regional center.

Increases in predicted income appear to increase the likelihood of migration from arctic villages to arctic regional centers. However, income doesn't appear to be an important driver of migration from regional centers to Anchorage or from Anchorage to destinations outside of Alaska. We find that subsistence place amenities don't appear to play an important role in migration up the hierarchy. In contrast, predicted subsistence appears to be an important determinant when migrating down the hierarchy. For Iñupiat migrants moving from Anchorage to arctic villages and arctic regional center's subsistence place amenities positively influence the probability of migration.

Last, we note that there appears to be important gender differences in hierarchical migration. Iñupiat women who leave villages are more likely than men to move directly to Anchorage, bypassing the regional center. In return migration to the Arctic from Anchorage men are more likely to move directly to arctic villages, bypassing the arctic regional centers, compared to women.

Preliminary results indicate that arctic migration follows a type of step-wise or hierarchal migration pattern. There are differences in these general patterns, however, in migration up the hierarchy and migration down the hierarchy, and sometimes between men and women. We also find that place amenities and predicted income are important but variable factors. In moving from villages to regional centers relative earnings is a key factor in the migration decision while things other than income play a more important role in migration from arctic regional centers to Anchorage (undoubtedly healthcare, schools, and other place amenities in Anchorage weigh heavily in this decision). In the decision to move down the hierarchy, again relative wages don't appear to be a driving factor. Rather, subsistence opportunities and station in life (e.g., elders and married couple families) appear to be more important than relative earnings in the migration decision. 


\section{References}

Alderman, H. and C. Paxson, 1994. "Do the poor insure? A synthesis of the literature on risk and consumption in developing countries." In Economics in a changing world editor Edmar L. Bacha, New York: St. Martins Press, pp. 48-78.

Alonso, W. and E. Rust. 1976. “The evolving pattern of village Alaska." Federal-State land Use Planning Commission for Alaska. Commission Study 17.

Berman, M. 2009. "Moving or staying for the best part of life: theory and evidence for the role of subsistence in migration and well-being of arctic Iñupiat residents." Polar Geography, 32(1), pp. 3-16.

Bureau of Economic Analysis (BEA). 2007. U.S. Department of Commerce, Regional Economic Information System. http://www.bea.gov/regional/index.htm

Cameron, C. and P. Trivedi. 2005. Microeconometrics: methods and applications. New York: Cambridge University Press.

Conway, D. 1980. “Step-Wise Migration: Toward a Clarification of the Mechanism.” International Migration Review, 14(1), pp. 3-14.

Geib, E. 2001. “Do Reservation Native Americans Vote with Their Feet? A Re-examination of Native American Migration, 1985-1990." American Journal of Economics and Sociology, 60(4), pp. 815-827.

Hamilton, L. and C.L. Seyfrit, and C. Bellinger. 1997. “Environment and sex ratios among Alaska Natives: an historical perspective." Population and Environment,18(3), pp. 283-299.

Hippler, A.E. 1969. "Patterns of migration, urbanization and acculturation of Alaska Natives." In Alaska public policy: current problems and issues, ed. Gordon Scott Harrison, Institute of Social, Economic and Government Research, University of Alaska Press: Fairbanks.

Howe, E.L. 2009. “Patterns of Migration in arctic Alaska.” Polar Geography, 32(1-2), pp. 69-89.

Krauss, Michael E. 1982. Native Peoples and Languages of Alaska. Fairbanks: Alaska Native Language Center.

Kruse, J. and K. Foster. 1986. "Changes in rural Alaska settlement patterns. Alaska Review of Social and Economic Conditions, 23(2), pp. 1-16.

Lucas, R.E.B. 2001. "The effects of proximity and transportation on developing country population migrations." Journal of Economic Geography, 1(3), pp. 323-329. 
McFadden, D. and Train, K. 2000. “Mixed MNL models for discrete responses.” Journal of Applied Econometrics, 15(5), pp. 447-470.

Plane, D. C. Henrie, and M. Perry. 2005. Migration up and down the urban hierarchy and across the life course. Proceedings of the National Academy of Sciences, 102(43), pp. 15313-15318.

Ravenstein, E.G., 1885. “The laws of migration.” Journal of the Statistical Society of London, 48(2), pp. 167-235.

Ravenstein, E.G., 1889. “The laws of migration: second paper.” Journal of the Royal Statistical Society, Vol. 52(2), pp. 241-305.

Rosenzweig, M.R. 2001. "Savings behaviour in low-income countries," Oxford Review of Economic Policy, 17(1), pages 40-54.

Rosenzweig, M. and O. Stark. 1989. “Consumption smoothing, migration and marriage: Evidence from rural India.” Journal of Political Economy, 97(4), pp. 905-926.

Stark, O. and R.E.B. Lucas. 1988. “Migration, remittances and the family." Economic Development and Cultural Change, 36(3), pp. 465-481.

Singh, I., L. Squire, and J. Strauss. 1986. "The basic model: theory, empirical results, and policy conclusions." In I. Sing, L. Squire, and J. Strauss, eds., Agricultural household models: extensions applications and policy, pp. 17-47.

SLiCA, 2003. Survey of Living Conditions in the Arctic. Institute of Social and Economic Research, University of Alaska Anchorage. http://www.arcticlivingconditions.org/

Tobler, W. 1995. “Migration: Ravenstein, Thorntwaite, and beyond.” Urban Geography, 16(4), pp. 327-343.

US Census Bureau. 2000. US Census 2000 Summary Data Files 1-4. 


\section{Appendix 1.}

Table 3. Reduced-form censored regression equations for household harvests (Berman, 2009)

\begin{tabular}{|l|r|r|}
\hline \multicolumn{3}{|c|}{ Y=Total household subsistence harvests } \\
\hline Personal Characteristics & \multicolumn{1}{|c|}{ Coef. } & \multicolumn{1}{l|}{ t-stat } \\
\hline Female & 0.0315 & $(0.79)$ \\
\hline Age & 0.01082 & $(1.81)$ \\
\hline Age squared & -0.0002 & $-(2.41)$ \\
\hline Education level & 0.0319 & $(1.54)$ \\
\hline Subsistence Skills & 0.0135 & $(3.24)$ \\
\hline disability status & -0.081 & $-(1.58)$ \\
\hline Family ties index & 0.025 & $(3.09)$ \\
\hline & & \\
\hline HH Characteristics & & \\
\hline Native lang at home & 0.0644 & $(3.83)$ \\
\hline N females aged 18+ in HH & 0.068 & $(2.51)$ \\
\hline N males aged 18+ in HH & 0.042 & $(1.50)$ \\
\hline N teens aged 16-17 in HH & 0.017 & $(0.46)$ \\
\hline N elders aged 65+ in HH & 0.0752 & $(1.72)$ \\
\hline Non-native HH member & 0.006 & $(0.15)$ \\
\hline No men in HH & -0.141 & $-(1.95)$ \\
\hline N kids under 16 in HH & 0.023 & $(1.82)$ \\
\hline N kids under five in HH & -0.0757 & $-(2.81)$ \\
\hline No men times kids < 5 & 0.097 & $-(1.60)$ \\
\hline & & \\
\hline Place Characteristics & -0.04128 & $-(0.52)$ \\
\hline Total Employment (1000's), 2000 & -0.206 & $-(2.04)$ \\
\hline Emp. Change, 1990-2000 & 0.136 & $(0.84)$ \\
\hline Regional Center & 0.0972 & $(2.05)$ \\
\hline Coastal Community & 0.142 & $(3.15)$ \\
\hline Caribou using community & 0.109 & $(2.28)$ \\
\hline Salmon Using community & -0.561 & $-(3.46)$ \\
\hline Intercept & & \\
\hline
\end{tabular}


Table 4. Ordinary least squares hourly wage regressions (lnhrwage)*

\begin{tabular}{|c|c|c|c|c|c|c|c|c|c|c|c|c|}
\hline & \multicolumn{2}{|c|}{$\begin{array}{c}\text { (Regression 1) } \\
\text { Out-Migration } \\
\text { From: Other Rural }\end{array}$} & \multicolumn{2}{|c|}{$\begin{array}{l}\text { (Regression 2) } \\
\text { Out-Migration } \\
\text { From: Villages }\end{array}$} & \multicolumn{2}{|c|}{$\begin{array}{l}\text { (Regression 3) } \\
\text { Out-Migration } \\
\text { From: Regional }\end{array}$} & \multicolumn{2}{|c|}{$\begin{array}{c}\text { (Regression 4) } \\
\text { Out-Migration From: } \\
\text { Anchorage }\end{array}$} & \multicolumn{2}{|c|}{$\begin{array}{c}\text { (Regression 5) } \\
\text { Out-Migration } \\
\text { From: Other Urban }\end{array}$} & \multicolumn{2}{|c|}{$\begin{array}{c}\text { (Regression 6) } \\
\text { Out-Migration From: } \\
\text { Other US }\end{array}$} \\
\hline & coef & t-stat & coef & t-stat & coef & t-stat & coef & t-stat & coef & t-stat & coef & t-stat \\
\hline age & 0.03572 & (5.60)a & 0.05620 & (6.00)a & 0.05402 & (3.99)a & 0.05986 & (6.12)a & 0.03742 & (3.05)a & 0.03857 & $(2.17) b$ \\
\hline agesq & -0.00032 & $-(3.99) a$ & -0.00058 & $-(4.94) a$ & -0.00054 & $-(3.15) a$ & -0.00057 & $-(4.53) \mathrm{a}$ & -0.00028 & $-(1.71) \mathrm{c}$ & -0.00032 & $-(1.44)$ \\
\hline female & -0.17317 & $-(6.50) a$ & -0.10276 & $-(2.49) a$ & -0.16937 & $-(2.75) a$ & -0.30517 & $-(7.28) a$ & -0.24094 & $-(6.52) a$ & -0.08739 & $-(1.12)$ \\
\hline hsgrad & 0.10558 & (2.75)a & 0.05411 & $(0.98)$ & 0.30801 & (3.90)a & 0.17749 & (2.52)a & 0.15364 & (2.57)a & 0.13641 & (1.03) \\
\hline somecoll & 0.34004 & (8.09)a & 0.15672 & (2.55)a & 0.37924 & (4.90)a & 0.30525 & (4.66)a & 0.30842 & (4.92)a & 0.23468 & $(1.85) \mathrm{c}$ \\
\hline badegree & 0.70964 & (10.10)a & 0.33768 & (2.85)a & 0.60178 & (6.21)a & 0.48088 & (5.95)a & 0.38780 & (4.04)a & 0.41493 & (2.73)a \\
\hline postbag & 0.77575 & (6.94)a & 0.74159 & $(1.71) \mathrm{C}$ & 0.62565 & (3.22)a & 0.65908 & (4.87)a & 0.77142 & (6.87)a & 0.69623 & (3.54)a \\
\hline veteran & 0.04270 & $(0.94)$ & -0.02715 & $-(0.42)$ & 0.00729 & $(0.08)$ & -0.07163 & $-(1.24)$ & 0.00399 & $(0.06)$ & 0.21611 & $(1.77) \mathrm{c}$ \\
\hline schlnow & -0.03340 & $-(0.75)$ & -0.28829 & $-(3.42) a$ & 0.10440 & $(1.20)$ & -0.03931 & $-(0.74)$ & 0.01736 & $(0.28)$ & -0.10094 & $-(0.91)$ \\
\hline _cons & 1.57156 & (14.01)a & 1.43620 & (8.24)a & 1.48112 & (6.07)a & 1.15035 & (7.01)a & 1.47411 & (7.31)a & 1.30730 & (3.89)a \\
\hline Observations & 4528 & & 1487 & & 767 & & 1331 & & 2360 & & 493 & \\
\hline F statistic & $49.88 \mathrm{a}$ & & $15.52 \mathrm{a}$ & & $16.8 \mathrm{a}$ & & $40.94 a$ & & $34.17 \mathrm{a}$ & & $9.3 \mathrm{a}$ & \\
\hline R-squared & 0.0927 & & 0.1023 & & 0.1523 & & 0.2318 & & 0.1397 & & 0.1711 & \\
\hline Root MSE & 0.81518 & & 0.71757 & & 0.68635 & & 0.62474 & & 0.7293 & & 0.71118 & \\
\hline
\end{tabular}


Table 5. Censored Tobit "hours worked" equations*

\begin{tabular}{|c|c|c|c|c|c|c|c|c|c|c|c|c|}
\hline & \multicolumn{2}{|c|}{$\begin{array}{c}\text { (Regression 1) } \\
\text { Out-Migration From: } \\
\text { Other Rural }\end{array}$} & \multicolumn{2}{|c|}{$\begin{array}{l}\text { (Regression 2) } \\
\text { Out-Migration } \\
\text { From: Villages }\end{array}$} & \multicolumn{2}{|c|}{$\begin{array}{c}\text { (Regression 3) } \\
\text { Out-Migration From: } \\
\text { Regional Centers }\end{array}$} & \multicolumn{2}{|c|}{$\begin{array}{c}\text { (Regression 4) } \\
\text { Out-Migration } \\
\text { From: Anchorage }\end{array}$} & \multicolumn{2}{|c|}{$\begin{array}{c}\text { (Regression 5) } \\
\text { Out-Migration From: } \\
\text { Other Urban }\end{array}$} & \multicolumn{2}{|c|}{$\begin{array}{l}\text { (Regression 6) } \\
\text { Out-Migration } \\
\text { From: Other US }\end{array}$} \\
\hline & coef & t-stat & coef & t-stat & coef & t-stat & coef & t-stat & coef & t-stat & coef & t-stat \\
\hline pwage_region & 74.66 & (14.52)a & 95.91 & (8.01)a & 95.38 & $(9.31)^{a}$ & 62.25 & $(6.30)^{a}$ & 44.64 & (5.43)a & 26.33 & $(1.45)$ \\
\hline youth & -514.23 & $-(11.04) \mathrm{a}$ & -617.64 & $-(5.86) \mathrm{a}$ & -376.48 & $-(2.74) \mathrm{a}$ & -673.46 & $-(6.28)^{a}$ & -743.22 & $-(9.00) a$ & -620.16 & $-(3.97) a$ \\
\hline elder & -1609.69 & $-(23.65) a$ & -1804.43 & $-(12.59) a$ & -1693.30 & $-(7.78) \mathrm{a}$ & -2370.0 & $-(11.4)^{a}$ & -2106.28 & $-(18.80) a$ & -1636.33 & $-(3.37) \mathrm{a}$ \\
\hline female & -60.08 & $-(2.09) b$ & 87.51 & $(1.62) \mathrm{C}$ & 139.06 & (1.66)a & -178.45 & $-(2.48)^{a}$ & -214.74 & $-(4.20) a$ & -433.16 & $-(4.30) \mathrm{a}$ \\
\hline married & 277.96 & (9.02)a & 302.67 & (5.32)a & 145.09 & (1.64)a & 50.40 & $(0.71)$ & 185.23 & (3.39)a & 74.60 & $(0.65)$ \\
\hline disabwk & -111.36 & $-(3.03) a$ & 232.13 & (3.29)a & -554.92 & $-(4.24) \mathrm{a}$ & -897.36 & $-(9.46)^{a}$ & -813.02 & $-(9.62) a$ & -440.19 & $-(3.07) \mathrm{a}$ \\
\hline native_lang & -315.08 & $-(10.53) a$ & -263.66 & $-(4.90) a$ & -220.30 & $-(2.60) a$ & -423.24 & $-(3.54)^{a}$ & -427.52 & $-(4.84) \mathrm{a}$ & -152.27 & $-(0.47)$ \\
\hline solohh & -5.09 & $-(0.10)$ & 73.84 & $(0.70)$ & 131.94 & $(0.88)$ & -110.43 & $-(0.98)$ & -16.51 & $-(0.20)$ & 216.20 & $(1.25)$ \\
\hline bighh & -159.93 & $-(5.22) a$ & -87.00 & $-(1.63) c$ & -176.87 & $-(2.01) b$ & -88.30 & $-(1.05)$ & -258.92 & $-(3.29) a$ & -302.04 & $-(1.65) c$ \\
\hline mom_un6 & -8.19 & $-(0.14)$ & 158.64 & $(1.51)$ & 320.31 & $(2.23) \mathrm{b}$ & -25.26 & $-(0.23)$ & -226.72 & $-(2.23) b$ & -412.87 & $-(2.06) \mathrm{a}$ \\
\hline empchange_region & 69.52 & $(2.86) \mathrm{a}$ & -158.01 & $-(1.92) \mathrm{c}$ & & & 212.09 & $(1.64)^{c}$ & -4.63 & $-(0.48)$ & & \\
\hline wemp00_region & 0.25 & $(10.62)$ & 0.63 & $(1.58)$ & -0.14 & $-(1.24)$ & 0.00 & $(2.14)^{\mathrm{b}}$ & 0.01 & $(2.53) \mathrm{a}$ & & \\
\hline coastal_region & -1.44 & $-(0.05)$ & 0.99 & $(0.01)$ & 91.77 & $(0.90)$ & & & -296.51 & $-(5.30) a$ & & \\
\hline caribou_region & -78.34 & $-(2.71) a$ & 318.58 & (5.98)a & & & 122.21 & (0.6) & -59.14 & $-(1.19)$ & & \\
\hline salmon_region & -176.08 & $-(1.76) \mathrm{c}$ & -78.54 & $-(1.50)$ & & & & & 108.71 & $(1.09)$ & & \\
\hline _cons & 344.02 & $(2.70) \mathrm{a}$ & -628.08 & $-(2.93) \mathrm{a}$ & -317.08 & $-(1.13)$ & 564.11 & $(1.88)^{\mathrm{c}}$ & 978.10 & (5.21)a & 1341.10 & (3.23)a \\
\hline /sigma & 1015.31 & & 1090.92 & & 1177.45 & & & & 1171.96 & & 1153.71 & \\
\hline Observations & 8209 & & 2852 & & 1337 & & & & 4554 & & 856 & \\
\hline F statistic & 158.63 & & 56.79 & & 40.18 & & & & 69.2 & & 10.5 & \\
\hline Pseudo R2 & 0.0289 & & 0.0333 & & 0.0302 & & & & 0.0262 & & 0.0147 & \\
\hline $\mathrm{Ll}$ & 5135.42 & & 320.091 & & 180.82 & & & & 4108.79 & & 777.534 & \\
\hline
\end{tabular}


Table 6. Choice of migration destinations: mixed multinomial logit (odds ratios presented as coefficients) *

\begin{tabular}{|c|c|c|c|c|c|c|c|c|c|}
\hline & & \multicolumn{2}{|c|}{$\begin{array}{c}\text { (Regression 1) } \\
\text { Out-Migration From: } \\
\text { Other Rural } \\
\end{array}$} & \multicolumn{2}{|c|}{$\begin{array}{c}\text { (Regression 2) } \\
\text { Out-Migration From: } \\
\text { Villages } \\
\end{array}$} & \multicolumn{2}{|c|}{$\begin{array}{c}\text { (Regression 3) } \\
\text { Out-Migration From: } \\
\text { Regional Centers } \\
\end{array}$} & \multicolumn{2}{|c|}{$\begin{array}{c}\text { (Regression 4) } \\
\text { Out-Migration From: } \\
\text { Anchorage } \\
\end{array}$} \\
\hline & & coef & t-stat & coef & t-stat & coef & t-stat & coef & t-stat \\
\hline \multicolumn{2}{|c|}{ predicted earnings } & 1.00 & $(0.10)$ & 1.00 & $(4.13) \mathrm{a}$ & 1.00 & $-(1.49)$ & 1.00 & $-(0.37)$ \\
\hline \multicolumn{2}{|c|}{ predicted subsistence } & 268.50 & $(4.66) \mathrm{a}$ & 0.004 & $-(1.09)$ & 23.46 & $(1.19)$ & 137209.50 & $(9.06) \mathrm{a}$ \\
\hline \multirow[t]{5}{*}{ female } & other rural & & & 0.29 & $-(0.87)$ & 3.13 & $(1.42)$ & 1.64 & $(2.30) \mathrm{b}$ \\
\hline & villages & 0.39 & $-(1.55)$ & & & 2.94 & $(1.62) \mathrm{c}$ & 0.78 & $-(0.77)$ \\
\hline & regional centers & 0.60 & $-(0.64)$ & 0.54 & $-(0.73)$ & & & 2.37 & $(2.34) \mathrm{b}$ \\
\hline & anchorage & 0.71 & $-(0.74)$ & 1.59 & $(0.56)$ & 2.37 & $(1.28)$ & & \\
\hline & other urban & 0.59 & $-(1.11)$ & 1.64 & $(0.46)$ & 2.29 & $(1.11)$ & 1.08 & $(0.28)$ \\
\hline \multirow[t]{5}{*}{ youth } & other rural & & & 3.54 & $(0.68)$ & 0.06 & $-(2.18) b$ & 0.61 & $-(1.47)$ \\
\hline & villages & 2.69 & $(1.31)$ & & & 0.11 & $-(2.82) \mathrm{a}$ & 0.44 & $-(1.62)$ \\
\hline & regional centers & 2.06 & $(0.72)$ & 7.23 & $(1.46)$ & & & 0.74 & $-(0.62)$ \\
\hline & anchorage & 0.45 & $-(1.37)$ & 6.06 & $(1.34)$ & 0.17 & $-(2.32) b$ & & \\
\hline & other urban & 0.68 & $-(0.64)$ & 0.00005 & $-(7.42) a$ & 0.39 & $-(0.93)$ & 0.57 & $-(1.32)$ \\
\hline \multirow[t]{5}{*}{ elder } & other rural & & & 0.31 & $-(0.76)$ & 0.04 & $-(3.34) \mathrm{a}$ & 0.64 & $-(0.68)$ \\
\hline & villages & 0.0003 & $-(6.90) \mathrm{a}$ & & & 6847.85 & $(8.42) \mathrm{a}$ & 1.14 & $(0.13)$ \\
\hline & regional centers & 0.0005 & $-(6.45) \mathrm{a}$ & 12345.54 & (8.72)a & & & 0.0003 & $-(17.64) \mathrm{a}$ \\
\hline & anchorage & 1.65 & $(0.43)$ & 6012.22 & (6.77)a & 3889.82 & $(5.62) \mathrm{a}$ & & \\
\hline & other urban & 2.89 & $(0.80)$ & 0.02 & $-(3.20) a$ & 0.02 & $-(4.22) a$ & 1.21 & $(0.25)$ \\
\hline \multirow[t]{5}{*}{ solohh } & other rural & & & 0.0002 & $-(5.77) \mathrm{a}$ & 1.25 & $(0.14)$ & 0.92 & $-(0.27)$ \\
\hline & villages & 0.0005 & $-(7.07) \mathrm{a}$ & & & 0.23 & $-(0.97)$ & 1.03 & $(0.07)$ \\
\hline & regional centers & 0.0008 & $-(6.39) a$ & 0.95 & $-(0.04)$ & & & 0.64 & $-(0.70)$ \\
\hline & anchorage & 2.41 & $(0.79)$ & 1.24 & $(0.17)$ & 1.55 & $(0.38)$ & & \\
\hline & other urban & 2.12 & $(0.66)$ & 3.78 & $(0.92)$ & 0.00 & $-(10.03) \mathrm{a}$ & 1.06 & $(0.11)$ \\
\hline \multirow[t]{5}{*}{ bighh } & other rural & & & 0.00002 & $-(6.00) \mathrm{a}$ & 6.03 & $(1.67) \mathrm{c}$ & 1.52 & $(1.21)$ \\
\hline & villages & 3.07 & $(1.69) \mathrm{c}$ & & & 19.38 & $(3.35) \mathrm{a}$ & 2.92 & $(2.33) \mathrm{b}$ \\
\hline & regional centers & 0.76 & $-(0.28)$ & 0.83 & $-(0.13)$ & & & 1.38 & $(0.65)$ \\
\hline & anchorage & 1.21 & $(0.33)$ & 0.17 & $-(1.07)$ & 13.67 & $(2.84) \mathrm{a}$ & & \\
\hline & other urban & 1.21 & $(0.32)$ & 0.00003 & $-(5.74) a$ & 10.31 & $(2.23) b$ & 2.89 & $(2.00) \mathrm{b}$ \\
\hline \multirow[t]{5}{*}{ married } & other rural & & & 5.66 & $(0.84)$ & 0.62 & $-(0.54)$ & 0.27 & $-(5.28) \mathrm{a}$ \\
\hline & villages & 1.37 & $(0.47)$ & & & 0.31 & $-(1.64) c$ & 0.25 & $-(3.70) a$ \\
\hline & regional centers & 2.62 & $(1.16)$ & 3.29 & $(0.80)$ & & & 0.30 & $-(3.21) \mathrm{a}$ \\
\hline & anchorage & 0.50 & $-(1.43)$ & 0.76 & $-(0.17)$ & 0.23 & $-(1.99) b$ & & \\
\hline & other urban & 0.66 & $-(0.81)$ & 0.00003 & $-(6.25) a$ & 0.94 & $-(0.07)$ & 0.53 & $-(2.00) b$ \\
\hline \multicolumn{2}{|r|}{ Wald chi2 } & $981.35 \mathrm{a}$ & & $2665.92 a$ & & $1033.35 a$ & & $1113.33 a$ & \\
\hline \multicolumn{2}{|c|}{ Log pseudolikelihood } & -1851.6354 & & -565.89526 & & -1007.1393 & & -3263.7721 & 0.53 \\
\hline \multicolumn{2}{|c|}{ \# of observations (\# of cases) } & $1585(317)$ & & $765(153)$ & & $860(172)$ & & $3800(760)$ & \\
\hline
\end{tabular}


Table 7. Marginal fixed effects

\begin{tabular}{|c|c|c|c|c|c|c|c|c|c|}
\hline & & \multicolumn{2}{|c|}{$\begin{array}{c}\text { (Regression 1) } \\
\text { Out-Migration From: } \\
\text { Other Rural }\end{array}$} & \multicolumn{2}{|c|}{$\begin{array}{c}\text { (Regression 2) } \\
\text { Out-Migration From: } \\
\text { Villages }\end{array}$} & \multicolumn{2}{|c|}{$\begin{array}{l}\text { (Regression 3) } \\
\text { Out-Migration From: } \\
\text { Regional Centers }\end{array}$} & \multicolumn{2}{|c|}{$\begin{array}{c}\text { (Regression } 4) \\
\text { Out-Migration From: } \\
\text { Anchorage }\end{array}$} \\
\hline & Destination & coef & z score & coef & z score & coef & z score & coef & z score \\
\hline \multirow{6}{*}{ 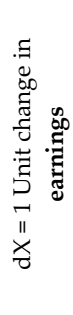 } & Other Rural & & & $4.40 \mathrm{E}-07$ & 2.3400 & $-2.90 \mathrm{E}-06$ & -1.5000 & $-7.70 \mathrm{E}-07$ & -0.3700 \\
\hline & arctic villages & $3.10 \mathrm{E}-08$ & 0.1000 & & & $-1.10 \mathrm{E}-05$ & -1.4800 & $-2.10 \mathrm{E}-07$ & -0.3600 \\
\hline & arctic regional centers & $1.80 \mathrm{E}-08$ & 0.1000 & $6.30 \mathrm{E}-05$ & 4.1400 & & & $-1.70 \mathrm{E}-07$ & -0.3700 \\
\hline & Anchorage / Mat-Su & $8.30 \mathrm{E}-07$ & 0.1000 & $6.20 \mathrm{E}-05$ & 3.9900 & $-1.80 \mathrm{E}-05$ & -1.4900 & & \\
\hline & Other Urban & $7.10 \mathrm{E}-07$ & 0.1000 & & & $-5.70 \mathrm{E}-06$ & -1.4500 & $-8.80 \mathrm{E}-07$ & -0.3700 \\
\hline & Other US & $3.50 \mathrm{E}-07$ & 0.1000 & $1.20 \mathrm{E}-05$ & 2.6300 & $-6.70 \mathrm{E}-06$ & -1.3300 & $-1.40 \mathrm{E}-06$ & -0.3700 \\
\hline \multirow{5}{*}{ 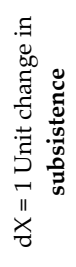 } & Other Rural & & & -0.010 & -1.00 & 0.123 & 1.09 & 1.572 & 8.01 \\
\hline & arctic villages & 0.051 & 2.96 & & & 0.465 & 1.17 & 0.440 & 5.32 \\
\hline & arctic regional centers & 0.030 & 2.45 & -1.413 & -1.09 & & & 0.354 & 4.95 \\
\hline & Anchorage / Mat-Su & 1.372 & 4.83 & -1.405 & -1.10 & 0.761 & 1.20 & & \\
\hline & Other Urban & 1.173 & 5.31 & & & 0.244 & 1.29 & 1.800 & 10.85 \\
\hline
\end{tabular}


Table 8. Choice of migration destinations: mixed multinomial logit (odds ratios presented as coefficients) *

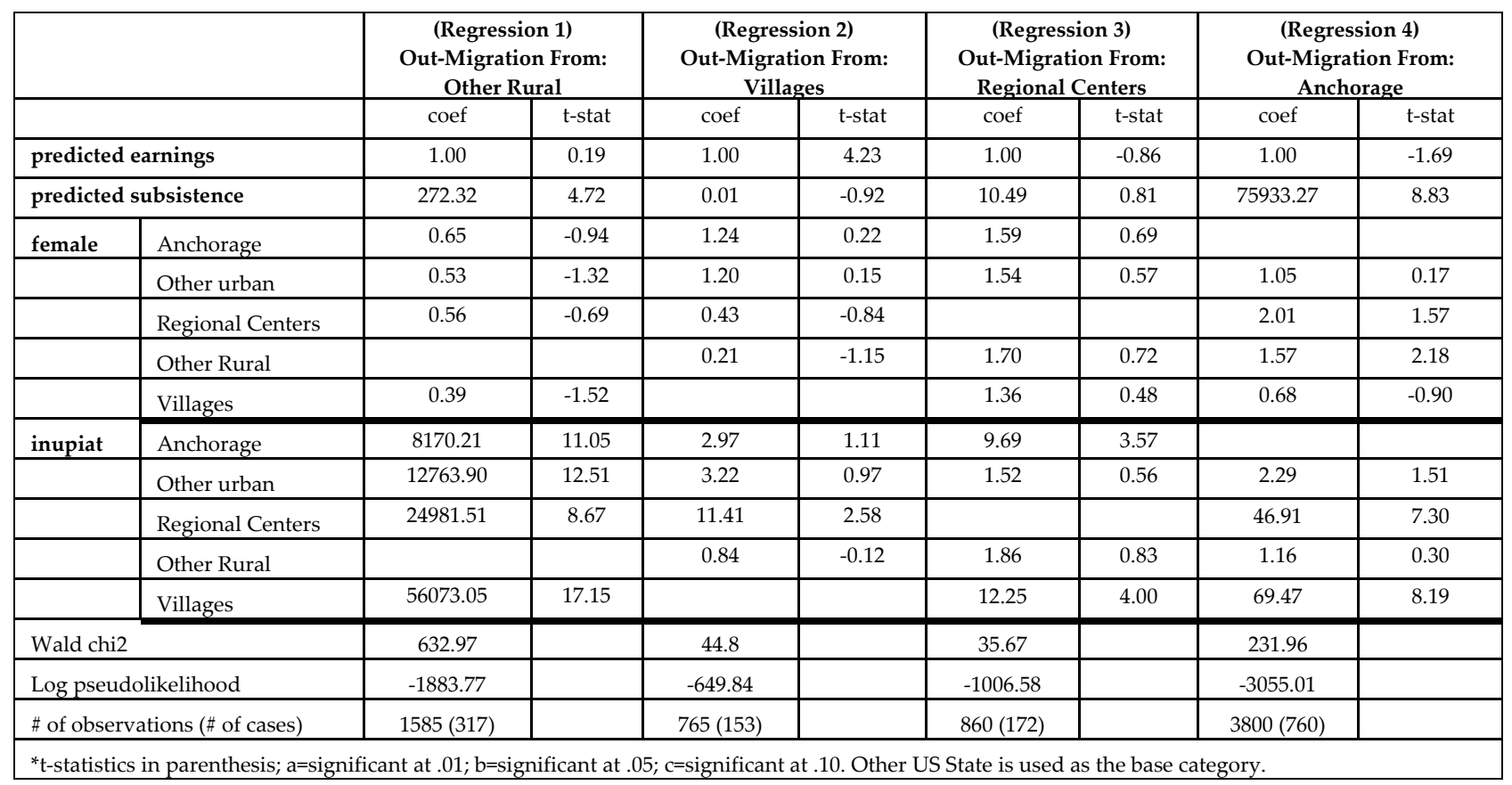

